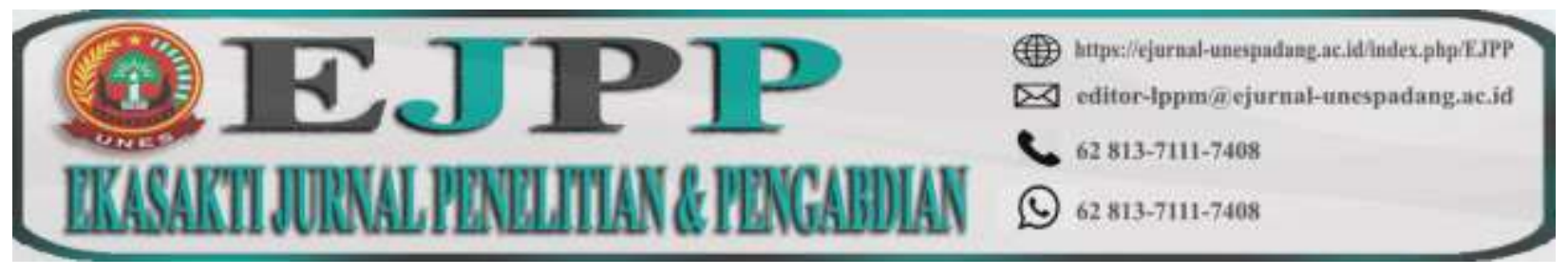

DOI: https://doi.org/10.31933/ejpp.v1i1.228

Received: 05/11/2020, Revised: 20/11/2020, Publish: 22/11/2020

\title{
PERLINDUNGAN HUKUM PEKERJA RUMAH TANGGA BERBASIS HAK KONSTITUSIONAL
}

\author{
Fadhli Junaidi ${ }^{1}$ \\ 1) Magister Administrasi Publik, Universitas Negeri Padang \\ Email: fadhlijunaidi@gmail.com
}

\begin{abstract}
ABSTRAK
Penelitian ini membahas tentang pentingnya perlindungan hukum berbasis hak konstitusional bagi PRT. Minimnya perhatian Pemerintah Indonesia terhadap PRT mengakibatkan majikan tidak memperlakukan PRT di Indonesia dengan baik. Permasalahan utama dalam tulisan ini adalah masih banyaknya permasalahan problematis yang terjadi pada PRT. Salah satunya adalah minimnya upah yang diterima PRT yang mengakibatkan terwujudnya hak asasi PRT berbasis konstitusional sesuai dengan Peraturan Menteri No.2 Tahun 2015 tentang Perlindungan PRT. Metode yang digunakan adalah penelitian kualitatif dengan pendekatan deskriptif. Teknik pengumpulan data berdasarkan studi pustaka dan dari jurnal online. Hasil analisis pasal ini adalah adanya perlindungan hukum bagi PRT yang telah diterapkan di Indonesia, seperti Undang-Undang Dasar Negara Republik Indonesia Tahun 1945, UndangUndang Nomor 13 Tahun 2003 tentang Ketenagakerjaan, KUH Perdata, dan Permenaker. RI No.2 Tahun 2015 tentang Perlindungan Hukum PRT yang berlaku di Indonesia diharapkan tidak lagi terjadi tumpang tindih antara majikan dan PRT yang tidak berdasarkan hak konstitusional.
\end{abstract}

Kata Kunci: Perlindungan Hukum, Pekerja Rumah Tangga, Hak Konstitusional.

\begin{abstract}
This research discusses the importance of constitutional rights-based legal protection for domestic workers. The lack of attention from the Government of Indonesia towards domestic workers results in employers not treating domestic workers in Indonesia well. The main problem in this paper is that there are still many problematic problems that occur in domestic workers. One of them is the minimum wage received by domestic workers which results in the realization of domestic workers' rights based on the constitution in accordance with Ministerial Regulation No.2 of 2015 on Protection of Domestic Workers. The method used is qualitative research with a descriptive approach. Technique based on literature study data and from online journals. The result of the analysis of this article is the existence of legal
\end{abstract}


protection for domestic workers that has been implemented in Indonesia, such as the 1945 Constitution of the Republic of Indonesia, Law Number 13 of 2003 concerning Manpower, the Civil Code, and the PERMENAKER. RI NO.2 of 2015 concerning the Legal Protection of Domestic Workers in effect in Indonesia is hoped that there will no longer be overlaps between employers and domestic workers who are not based on constitutional rights.

Keywords: Legal Protection, Domestic Workers, Constitutional Rights.

\section{PENDAHULUAN}

Kebutuhan akan Pekerja Rumah Tangga (PRT) di Indonesia dewasa ini semakin meningkat, ini terjadi umumnya di masyarakat perkotaan yang akrab dengan laju industrialisasi yang memungkinkan para perempuan yang identik sebagai pelaksana pekerjaan di rumah tangga juga harus bekerja di ruang publik, sehingga pekerjaan yang rumah tangga yang tidak mampu dikerjakannya lagi harus diserahkan pada PRT. Pekerja Rumah Tangga seringkali tidak dimasukkan dalam kategori pekerjaan sektor informal. Para ekonom lebih banyak memaknai sektor informal sebagai Usaha kecil dan menengah, pengasuh bayi, pekerja jalanan. Sedangkan di Indonesia masih sering pekerja rumah tangga dianggap profesi membantu pekerjaan rumah tanngga. Sesungguhnya pekerja rumah tangga adalah bagian dari pekerjaan sektor informal meskipun belum ada aturan hukum yang mengaturnya di Indonesia. Pekerja rumah tangga sering berasal dari kelompok masyarakat miskin. Mereka bekerja dengan terjerat kemiskinan struktural dan pendidikan yang rendah sehingga memaksa pekera rumah tangga bekerja dengan rekasi kuasa yang timpang dan posisi tawar diskriminasi yang berbentuk kekerasan fisik, psikis, tidak memiliki kebebasan mengambil keputusan karena terjerat utang dengan pemberi kerja, pembatasan kebebasan secara fisik dan masih banyak lagi.

Dalam Nurjannah. S (2012) disebutkan bahwa tenaga kerja merupakan subyek hukum yang mempunyai hak dan kewajiban untuk mendapat perlindungan. Aspek hukum ketenagakerjaan, harus selaras dengan perkembangan ketenagakerjaan saat ini yang sudah sedemikian pesat, sehingga substansi kajian hukum ketenagakerjaan tidak hanya meliputi hubungan kerja semata, akan tetapi telah bergeser menjadi hubungan hukum antara pekerja, pengusaha, dan pemerintah yang substansi kajian tidak hanya mengatur hubungan hukum dalam hubungan kerja, tetapi setelah hubungan kerja.

Kansil (2002) mengatakan bahwa hukum adalah rangkaian peraturan-peraturan mengenai tingkah laku orang- orang sebagai anggota masyarakat, dan tujuan hukum itu adalah mengadakan keselamatan, kebahagiaan, dan tata tertib di dalam masyarakat. Menurut Hardianto Djanggih dalam Anggie Rizqita (2019) Indonesia adalah negara hukum, segala perbuatan di Indonesia diatur dan terikat hukum. Hukum itu sendiri bukan hanya soal petunjuk dan pedoman tingkah laku manusia dalam masyarakat, tetapi hukum juga harus benar- benar hidup di dalam masyarakat itu agar dapat mencapai ketertiban dan perdamaian dalam masyarakat. Sebagai negara hukum, di Indonesia juga terdapat Hak Asasi Manusia (HAM) yang dimiliki oleh setiap individu sejak individu tersebut dilahirkan. Hak asasi tersebut diantaranya adalah hak hidup, hak 
kemerdekaan, dan hak milik. Pekerja Rumah Tangga atau yang biasa disingkat PRT juga memiliki hak dalam bekerja, hak untuk mendapatkan perbuatan yang wajar dari pemberi kerja.

Di Indonesia hak untuk bekerja merupakan hak dasar setiap manusia (Pasal 27 ayat (2) UUD Tahun 1945) : "Tiap-tiap warga negara berhak atas pekerjaan dan penghidupan yang layak bagi kemanusiaan", bahkan diyakinkan sebagai hak asasi manusia (Pasal 28D ayat 2 UUD 1945): "Setiap orang berhak untuk bekerja serta mendapat imbalan dan perlakuan yangadil dan layak dalam hubungan kerja." Cukuplah kuat sebenarnya alasan Indonesia untuk membuat peraturan perlindungan bagi warga negaranya apapun jenis pekerjaannya agar mendapat pekerjaan dan penghidupan yang layak dari pekerjaan tersebut, tak terkecuali adalah pekerja rumah tangga (PRT).

Pada Undang Undang Nomor 13 Tahun 2003 Tentang Ketenagakerjaan disebutkan bahwa pekerja adalah setiap orang yang bekerja dengan menerima upah atau imbalan dalam bentuk lain. Jika merujuk dari pengertian yang dinormatifkan dalam Undang Undang Nomor 13 Tahun 2003 ini, mestinya PRT termasuk bagian di dalamnya. Sitti Magfirah Makmur (2020) mengatakan hal ini disebabkan karena PRT adalah orang yang bekerja dengan menerimah upah atau imbalan dalam bentuk lain. Akan tetapi, Undang-undang ini secara substantif tidak mengatur tentang PRT. Pada akhirnya PRT tidak akan memiliki pegangan hukum untuk melindungi dirinya jika tidak ada turunan hukum lain yang dapat memberikan jaminan.

Menurut Sri Turatmiyah dalam Ismiatun (2017), menjelaskan bahwa beberapa faktor yang mengakibatkan masih lemahnya perlindungan hukum dan sosial bagi perempuan sebagai Pekerja Rumah Tangga, baik aspek yuridis maupun aspek sosial. Aspek yuridis, meliputi: pertama, adanya anggapan bahwa Pekerja Rumah Tangga bukan pekerja; dan kedua, tempat kerja Pekerja Rumah Tangga berpotensi menimbulkan kekerasan. Aspek sosial meliputi: pertama, relasi kekuasaan yang tidak seimbang; kedua, status sosial Pekerja Rumah Tangga yang rendah dan kurang dihargai, dan ketiga, kultur masyarakat; serta pekerjaan yang dilakukan Pekerja Rumah Tangga tidak dianggap sebagai pekerjaan produktif.

Permasalahan yang terjadi terkait PRT di Indonesia adalah mengenai jam kerja, UU Ketenagakerjaan mengatur, pemberi kerja harus memperhatikan keputusan tentang jam kerja dimana tidak ada ketentuan yang menetapkan jam kerja untuk PRT. Survei menunjukkan, PRT bekerja selama lebih dari 40 jam seminggu. Secara spesifik, 63\% PRT di Indonesia bekerja tujuh hari seminggu tanpa libur. Permasalahan lainnya, dalam hal upah minimum. Permenaker mengatur bahwa PRT berhak menerima upah sesuai dengan perjanjian kerja, namun sampai saat ini tidak diatur mengenai upah minimum.. Dalam praktiknya, upah minimum PRT ditentukan oleh Pemerintah daerah setempat. Sampai saat ini perlindungan tenaga kerja PRT masih memiliki isu yang belum dapat diselesaikan. Untuk itu dalam artikel ini melihat bagaimana rangkuman hasil penelitian dari para peneliti agar dapat terpecahkan perlindungan hukum pekerja rumah tangga berbasis hak konstitusional. (Berita yang dimuat pada Koran Berita Satu, Media Holdings, Ditulis oleh Dosen Universitas Pelita Harapan).

Berdasarkan Peraturan Menteri Nomor 2 Tahun 2015 Tentang Perlindungan Pekerja Rumah Tangga, pekerja rumah tangga adalah seseorang yang bekerja dan melakukan tugas- 
tugas domestik di dalam rumah tangga seseorang (yang disebut majikan/ pengguna jasa). Ratarata mereka bekerja hanya berdasarkan kesepakatan lisan, tanpa perjanjian atau kontrak kerja tertulis yang berisi tentang hak dan kewajiban masing- masing pihak (PRT dan Majikan). Dari berita yang dimuat pada (Antara News: 2008) disebutkan bahwa tingginya kasus kekerasan terhadap PRT di Indonesia menunjukkan beberapa hal, pertama perlu adanya instrumen yuridis untuk mencegah berulangnya dan berlanjutnya kekerasan terhadap PRT, kedua, belum cukup efektifnya peraturan yang kini ada untuk mencegah dan menghentikan kekerasan terhadap PRT. Ketiga, rentan dan lemahnya perlindungan hukum terhadap PRT di tempat kerja. Dari uraian tersebut, tulisan ini dimaksudkan untuk mengetahui perlindungan hukum pekerja rumah tangga berbasis konstitusional.

\section{METODE PENELITIAN}

Metode yang digunakan dalam artikel ini adalah penelitian kualitatif dengan pendekatan deskriptif. Penelitian kualitatif adalah penlitian yang bermaksud untuk memahami fenomena tentang apa yang dialami oleh subjek penelitian misalnya perilaku, persepsi, motivasi, tindakan, dan lain-lain, secara holistic dan dengan cara deskripsi dalam bentuk kata-kata dan bahasa, pada suatu konteks khusus yang alamiah dan dengan memanfaatkan berbagai metode ilmiah (Moleong: 2009). Teknik pengambilan data berdasarkan studi kepustakaan dan dari jurnal online. Dari pengumpulan data tersebut kemudian dianalisis sebagai pembahasan dan ditarik kesimpulan sebagai jawaban dari permasalahan yang ada.

\section{HASIL DAN PEMBAHASAN}

\section{Perlindungan Hukum terkatit Pekerja Rumah Tangga}

Dalam buku yang ditulis oleh Muhadar, Edu Abdullah (2009) mengatakan perlindungan adalah suatu bentuk pelayanan yang dilaksanakan oleh aparat penegak hukum atau aparat keamanan untuk memberikan rasa aman baik fisik maupun mental, kepada korban dan saksi dari ancaman gangguan terror dan kekerasan dari pihak manapun yang diberikan pada tahap penyelidikan, penyidikan dan penuntutan dan atau pemeriksaan di sidang pengadilan. Perlindungan hukum bila dijelaskan secara harfiah dapat menimbulkan banyak persepsi. Sebelum mengurai perlindungan hukum dalam makna yang sebenarnya dalam hukum, menarik pula untuk mengurai sedikit mengenai pengertian-pengertian yang dapat timbul dari penggunaan istilah perlindungan hukum. Menurut (Mertokusumo: 2009) menyebutkan perlindungan hukum bisa berarti perlindungan yang diberikan terhadap hukum agar tidak ditafsirkan berbeda dan tidak cederai oleh aparat penegak hukum dan juga bisa berarti perlindungan yang diberikan oleh hukum terhadap sesuatu. Dalam Undang- Undang dasar Tahun 1945 Pasal 28 D Ayat (1) disebutkan bahwa "setiap orang berhak atas pengakuan, jaminan, perlindungan dan kepastian hukum yang adil serta perlakuan yang sama di hadapan hukum."

Untuk memberikan dan menjalankan suatu perlindungan hukum, diperlukan suatu wadah atau tempat dalam implementasinya yang sering disebut sebagai sarana perlindungan hukum. 
Philipus M. hajdon dalam Arfan Kaimudin (2019) membagi sarana perlindungan hukum menjadi dua macam yang dapat dipahami, sebagai berikut:

1. Perlindungan Hukum Preventif, yaitu perlindungan hukum dimana rakyat memiliki kesempatan untuk mengajukan keberatan (inspraak) atau pendapatnya sebelum sesuatu keputusan pemerintah mendapat bentuk yang definive. Dengan demikian perlindungan hukum preventif bertujuan untuk mencegah terjadinya suatu sengketa. Perlindungan hukum preventif sangat besar artinya bagi tindakan pemerintah yang didasarkan pada kebebasan bertindak karena dengan perlindungan hukum tersebut, pemerintah didorong untuk bersikap hati-hati dalam pengambilan keputusan.

2. Perlindungan Hukum Represif, yaitu upaya untuk perlindungan hukum yang dilakukan melalui badan peradilan, baik peradilan umum maupun peradilan administrasi negara. Perlindungan hukum represif bertujuan untuk menyelesaikan sengketa.

Perlindungan hukum oleh Negara/Pemerintah lebih ditekankan pada unsur Negara/Pemerintah sebagai pemegang kedaulatan. Untuk itu, perlindungan hukum yang diberikan oleh Negara/Pemerintah kepada warga negara dapat dilihat dalam instrument hukum dan kebijakan yang dikeluarkan oleh Pemerintah. Peraturan perundang- undangan Ketenagakerjaan yang berlaku di Indonesia adalah sebagai berikut:

a. Kitab Undang-Undang Hukum Perdata, khususnya Pasal 1313,1338, dan 1320.

b. Undang- Undang RI No.13 Tahun 2003 tentang Ketenagakerjaan.

c. Peraturan Pemerintah Republik Indonesia No.31 tahun 2006 tentang Sistem Pelatihan Kerja Nasional.

d. Keputusan Menteri Tenaga Kerja RI No. KEP.100/MEN/VI/2004 tentang Ketentuan Pelaksanaan Perjanjian Kerja Waktu Tertentu.

e. Keputusan Menteri Tenaga Kerja RI No. KEP.48/MEN/IV/2004 tentang Tata Cara Pembuatan dan Pengesahan Peraturan Perusahaan serta Pembuatan dan Pendaftara Kerjanjian Kerja Bersama, dan sebagainya.

Sumber Hukum Perlindungan Pekerja Rumah Tangga adalah sebagai berikut:

1) Undang- Undang dasar Negara Republik Indonesia Tahun 1945.

2) Undang- Undang No.13 Tahun 2003 tentang Ketenagakerjaan.

3) Kitab Undang- Undang Hukum Perdata.

4) Permenaker RI No. 2 Tahun 2015 tentang Perlindungan Hukum Bagi Pekerja Rumah tangga.

Dengan adanya sumber-sumber hukum sebagai bentuk perlindungan hukum pekerja rumah tangga tersebut diatas, diharapkan untuk kedepannya Pemerintah lebih memperhatikan hak setiap pekerja rumah tangga yang ada di Indonesia. Sehingga peraturan atau keputusan yang yang sudah dibuat dapat dilaksanakan dengan baik oleh pemberi kerja. Dengan demikian dapat dipastikan bahwa perlindungan hukum bagi pekerja rumah tangga dapat terjamin dengan baik. 


\section{Perlindungan Hukum Pekerja Rumah Tangga Berbasis Hak Konstitusional (Berdasarkan Peraturan Menteri Nomor 2 Tahun 2015 Tentang Perlindungan Pekerja Rumah Tangga)}

Secara spesifik, pengaturan PRT diatur dalam Peraturan Menteri Tenaga Kerja Nomor 2 Tahun 2015 Tentang Perlindungan PRT. Salah satu yang unik dari Peraturan Menteri ini adalah aturan dibuat bukan karena derivasi atau perintah dari Undang Undang No 13 Tahun 2003 Tentang Ketenagakerjaan melainkan dari Undang Undang No 23 Tahun 2014 tentang Pemerintahan Daerah yang sama sekali tidak ada keterkaitannya. Di dalam pasal 7 Peraturan Menteri Tenaga Kerja Nomor 2 Tahun 2015 Tentang Perlindungan PRT disebutkan bahwa PRT mempunyai hak:

1. Memperoleh informasi mengenai Pengguna;

2. Mendapatkan perlakuan yang baik dari Pengguna dan anggota keluarganya;

3. Mendapatkan upah sesuai Perjanjian Kerja;

4. Mendapatkan makanan dan minuman yang sehat;

5. Mendapatkan waktu istirahat yang cukup;

6. Mendapatkan hak cuti sesuai dengan kesepakatan;

7. Mendapatkan kesempatan melakukan ibadah sesuai dengan agama dan kepercayaan yang dianutnya;

8. Mendapatkan tunjangan hari raya; dan

9. Berkomunikasi dengan keluarganya.

Berdasarkan hasil penelitian yang dilalukan oleh Windi Arista (2019) menyebutkan bahwa perlindungan terhadap pekerja/tenaga kerja menurut Zaeni Asyhadie "dapat dilakukan baik dengan jalan memberikan tuntunan, santunan, maupun dengan jalan meningkatkan pengakuan hak-hak asasi manusia, perlindungan fisik dan sosial ekonomi melalui norma yang berlaku dalam majikan". Menurut Abdul Khakim Windi Arista (2019), membagi 3 (tiga) macam perlindungan terhadap pekerja/tenaga kerja, masing-masing:

a. Perlindungan ekonomis, yaitu perlindungan tenaga kerja dalam bentuk penghasilan yang cukup, termasuk bila tenaga kerja tidak mampu bekerja di luar kehendaknya.

b. Perlindungan sosial, yaitu perlindungan tenaga kerja dalam bentuk jaminan kesehatan kerja, dan kebebasan berserikat dan perlindungan hak untuk berorganisasi.

c. Perlindungan teknis, yaitu perlindungan tenaga kerja dalam bentuk keamanan dan keselamatan kerja.

Menurut Imam Soepomo dalam Windi Arista (2019), pemberian pelindungan pekerja meliputi lima bidang hukum perpekerjaan, yaitu pengerahan/penempatan tenaga kerja, hubungan kerja, kesehatan kerja, keamanan kerja;, dan jaminan sosial pekerja. Sakka Patti (2012) mencatat beberapa fakta tidak terlindunginya pekerja rumah tangga sebagai berikut:

1) Aturan yang mengatur tentang pekerja rumah tangga belum ada.

2) Faktanya hubungan hukum antara pekerja rumah tangga dengan pemberi kerja pada umumnya tidak didasari oleh suatu perjanjian kerja.

3) Pekerja rumah tangga seringkali dikecualikan dari cakupan upah minimum.

4) Upah seringkali digunakan sebagai alat pengendalian.

5) Pembayaran upah terkadang terlambat bahkan sering tidak terbayarkan. 
6) Kamar dan tempat tinggal serta makanan biasaya dianggap sebagai satu bentuk pembayaran.

7) Perbedaan yang signifikan antara standar jam kerja yang berlaku secara umum dan standar jam kerja yang berkenaan dengan pekerja rumah tangga.

Fakta inilah yang masih terjadi di Indonesia, sehingga membuat hak setiap pekerja rumah tangga tidak terpenuhi dengan baik. Namun katerna susahnya mencari pekerjaan karena keterbatasan latar belakang pendidikan membua para pekerja rumah tangga (perempuan) untuk menerima kenyataan dan tetap bekerja walaupun dalam kondisi yang terbebani. Disinilah perlu adanya perlindungan hukum bagi pekerja rumah tangga yang harus benar- benar diterapkan oleh Pemerintah Indonesia.

Selanjutnya berdasarkan hasil penelitian yang dilakukan oleh Agusmidah (2017) mengatakan bahwa Konvensi Kerja Layak PRT (K ILO No. 189 KERJA LAYAK PRT) ini menjadi Sejarah Sosial Baru untuk Dunia yang lebih beradab dan berkeadilan, khusunya bagi 100 juta PRT di dunia yang mayoritas adalah perempuan dan sebagian adalah berusia anak, termasuk lebih dari 10 juta PRT yang bekerja di Indonesia dan lebih dari 6 juta PRT migran Indonesia. Konvensi ini memberikan pengakuan PRT sebagai pekerja dan memberikan penghormatan dan perlindungan atas hak-hak yang melekat padanya dan situasi kerja layak PRT sebagaimana Pekerja yang lainnya. Konvensi dengan disertai Rekomendasi ini memuat standar sebagai berikut:

1. Prinsip-prinsip fundamental perlindungan hak-hak dan situasi kerja serta keadilan sosial bagi Pekerja Rumah Tangga dengan mengacu pada berbagai instrumen internasional tentang HAMm, penghapusan bentuk diskriminasi terhadap perempuan, hak-hak sipil dan ekosob, perlindungan hak anak, perlindungan buruh migrant.

2. Pengakuan kontribusi sosial ekonomi PRT yang sangat signifikan untuk keluarga majikan dan untuk ekonomi global.

3. Penghapusan segala bentuk diskriminasi terhadap PRT, perlindungan dari pelanggaran hak-hak, kesewenang-wenangan, dan kekerasan terhadap PRT, penghapusan kerja paksa.

4. Penghormatan atas hak berserikat dan, ruang serta peran bernegosiasi secara setara dalam dialog sosial.

5. Penghapusan PRT Anak.

6. Hak-hak dan syarat-syarat kondisi kerja layak PRT yang tercermin dalam kandungan pasal-pasalnya (ada 27 Pasal) yaitu:

a. definisi,

b. cakupan;perlindungan HAM PRT;

c. batasan usia minimum bekerja sebagai PRT dan penghapusan PRTA;

d. Kontrak Kerja dan muatan kontrak kerja mengenai identitas, alamat kedua belah pihak dan tempat kerja, hak-hak dan situasi kerja layak;

e. perlindungan buruh migran;

f. privasi dan hak atas dokumennya; 
g. jam kerja, libur mingguan;

h. upah minimum dan pembayaran termasuk bentuk, batasan pembayaran, metode, waktu pembayaran;

i. kesehatan dan keselamatan kerja;

j. jaminan sosial termasuk jaminan melahirkan;

k. akomodasi dan konsumsi;

1. pendidikan dan pelatihan;

m. mekanisme pengaduan;

n. monitoring;

o. perlindungan khusus PRT Migran;

p. kerjasama antar negara dalam menjamin pelaksanaan konvensi.

Selain itu, Nur Hidayati (2015) juga mengatakan bahkan pemerintahpun tidak pernah menggagas kampanye untuk membangkitkan kepedulian terhadap PRT. Namun demikian terdapat beberapa hal yang barangkali diagendakan sebagai upaya berarti untuk memberikan perlindungan terhadap PRT antara lain:

1) Law Reform (Reformasi Hukum)

Pembaharuan hukum yang diformulasikan dalam berbagai kebijakan berbasis keberpihakan kepada PRT dalam kerangka perlindungan dan pemberdayaan serta pembinaan hubungan kerja. Law Reform ini dilakukan terhadap UU No. 13 tahun 2003 sebagai hasil evaluasi dan pengkajian atas realitas hubungan PRT dan pemberi kerja berikut problem yang menyertainya. Dengan adanya konvensi ILO No. 189, merupakan momentum bagi pemerintah di bidang hukum untuk segera melakukan ratifikasi, bahkan lebih penting dan mendasar sebagai wujud komitmen dan konsistensinya, pemerintah segera membentuk perundang-undangan (law making) yang khusus memberikan perlindungan terhadap PRT.

2) Advocacy

Mengangkat ke permukaan kasus-kasus PRT agar memperoleh respons banyak pihak guna menjadi agenda dalam upaya perubahan ke arah yang lebih baik.

3) Paralegal

Sebagai bentuk penyadaran hukum dan aksi untuk melindungi PRT dari berbagai tekanan pemberi kerja.

4) Perlu dibentuk pusat-pusat pelayanan

Pusat pelayanan sebagai bagian dari bentuk pengorganisasian, termasuk upaya untuk menggagas terbentuknya organisasi serikat pekerja khusus PRT. Pembentukan serikat pekerja dalam hal ini tidak berarti menciptakan kaidah dari tidak ada menjadi ada tetapi juga menempatkan komunitas PRT secara afiliatif organisatoris terhadap serikat pekerja yang sudah mapan, seperti SPSI, SARBUMUSI dan sebagainya.

Dari hasil penelitian tersebut, Nur Hidayati (2015) juga mengatakan bahwa berdasarkan Permenaker No. 2 tahun 2015 tentang Perlindungan Terhadap Pembantu Rumah Tangga (PRT) belum bisa menjangkau UU No.13 tahun 2003 dalam hubungan kerja. Karena PRT dianggap 
tidak dipekerjakan "pengusaha", PRT tidak mendapatkan perlindungan yang diberikan undangundang terhadap pekerja lainnya. Disamping itu, akses terhadap mekanisme penyelesaian perselisihan kerja, seperti pengadilan industrial yang dibentuk menurut UU No. 22 tahun 2004 tentang Penyelesaian Perselisihan Hubungan Industrial. Berdasarkan penafsiran substansi UU No. 13 tahun 2003 tersebut secara hukum PRT tidak mendapatkan perlindungan hukum. Permenaker No. 2 tahun 2015 tidak memerinci hak-hak sebagai pekerja seperti standarisasi upah, pengaturan jam kerja dan waktu istirahat, cuti mingguan, dan cuti tahunan, hak untuk berkomunikasi dan berserikat, serta perjanjian tertulis dan bukan lisan. Apabila hak-hak tersebut dalam Permenaker No. 2 tahun 2015 tidak diperjelas pemerintah dalam UU maka pelanggaran PRT akan dianggap sebagi hal yang biasa, bahkan mengarah perbudakan modern sementara mandat UU Indonesia, seharusnya negara mengakhiri perbudakan di negeri sendiri.

Selain itu Ida Hanifah (2020) menemukan dari hasil penelitian yang dilakukannya, alasan PRT membutuhkan perlindungan hukum, dari negara karena:

a) PRT tidak diakui sebgai profesi. PRT tidak dianggap profesi sehingga PRT tidak mendapatkan hak konstitusional dan hukum sebagai profesi. Dengan demikian, sebagai PRT tidak mendapatkan jaminan perlindungan hukum sebagai pekerja pada umumnya.

b) Banyak PRT tidak memiliki hubungan keluarga dengan majikan. Misalnya PRT yang merantau ke perkotaan dan tidak ada mengenal siapapun, apalagi tidak memiliki hubungan keluarga dengan majikannya.

c) PRT itu Unik. PRT tidak mempunyai persediaan dan struktur kerja teratur, program dan pengembangan sistem sehingga mempunyai keunikan sendiri. Keunikan PRT adalah bahwa hubungan hukum yang terjadi sebagian besar didasrkan pada hubungan keluarga atau hubungan darah.

d) Tidak ada standar kerja untuk PRT sebbagai pekerja. Banyak pihak tidak melihat PRT tidak sebagai pekerja, bahkan tidak secara resmi termasuk dalam data. Fakta ini membuktikan bahwa pemerintah tidak mengenali PRT sebagai bagian dari tenaga kerja, mungkin data PRT merupakan bagian dari data pengangguran di Indonesia.

Selanjutnya, pendapat berbeda dari Rizky Meitha (2013) melalui hasil penelitiannya mengatakan bahwa faktor-faktor yang menghambat perlindungan hukum terhadap PRT antara lain adalah aspek yuridis meliputi adanya anggapan bahwa PRT bukan pekerja; dan tempat kerja PRT berpotensi menimbulkan kekerasan. Sedangkan aspek sosial meliputi relasi kekuasaan yang tidak seimbang; status sosial PRT yang rendah dan kurang dihargai; kultur masyarakat; dan pekerjaan yang dilakukan PRT tidak dianggap sebagai pekerjaan produktif. Oleh karena itu, diharapkan Aparat Penegak Hukum dapat mengoptimalkan peranya dalam memberikan Perlindungan dan Pelayanan terhadap Kasus PRT. Mencermati kondisi sekarang ini sangat diperlukan peraturan perundang-undangan yang mengatur secara khusus perlindungan hukum terhadap PRT dengan dibuatnya Undang-Undang tentang PRT. Undang-Undang tersebut berguna sebagai payung hukum dalam memberikan perlindungan hukum terhadap PRT. Mengingat PRT sebagian besar adalah perempuan maka sebaiknya PRT perempuan harus di beri perlindungan yang sama seperti pekerja lain. 
Selain itu Dwi Astuti dalam Ismiatun (2017) mengatakan keberadaan peraturan perundang undangan sangat penting untuk memberikan perlindungan hukum kepada para Pekerja Rumah Tangga dalam memperoleh hak-hak mereka dan melaksanakan kewajiban mereka. Tentunya hal ini berlaku juga bagi para pengguna jasa yang mempekerjakan pekerja rumah tangga. Kedua belah pihak dapat terhindar dari penyalahgunaan kekuasaan dalam hubungan kerja di antara pekerja rumah tangga dan pengguna jasanya. Adanya pengakuan secara sosial dan hukum tentunya akan memudahkan dalam membuat peraturan perundang undangan yang secara langsung memberikan perlindungan kepada para Pekerja Rumah Tangga. Maka, acuan yuridis pun menjadi jelas bagi pekerja rumah tangga dan pengguna jasa pekerja rumah tangga serta masyarakat.

Dengan adanya pendapat dari beberapa peneliti tersebut di atas, dapat disimpulkan bahwa walaupun masih ada isu permasalahan perlindungan hukum mengenai hak pekerja rumah tangga di Indonesia. Pemerintah Indonesia telah berupaya semaksimal mungkin untuk memperjuangkan hak asasi manusia pekerja rumah tangga dengan menerapakan peraturan perundang-undangan yang secara langsung bertujuan memberikan perlindungan hukum bagi pekerja rumah tangga. Beberapa Sumber Hukum Perlindungan Pekerja Rumah Tangga yang ada di Indonesia adalah sebagai berikut:

1. Undang- Undang dasar Negara Republik Indonesia Tahun 1945.

2. Undang- Undang No.13 Tahun 2003 tentang Ketenagakerjaan.

3. Kitab Undang- Undang Hukum Perdata.

4. Permenaker RI No.2 Tahun 2015 tentang Perlindungan Hukum Bagi Pekerja Rumah tangga.

\section{KESIMPULAN}

Adapun kesimpulan dalam penelitian ini adalah sebagai berikut:

1. Untuk memberikan dan menjalankan suatu perlindungan hukum, diperlukan suatu wadah atau tempat dalam implementasinya yang sering disebut sebagai sarana perlindungan hukum.

a. Perlindungan Hukum Preventif, yaitu perlindungan hukum dimana rakyat memiliki kesempatan untuk mengajukan keberatan (inspraak) atau pendapatnya sebelum sesuatu keputusan pemerintah mendapat bentuk yang definive.

b. Perlindungan Hukum Represif, yaitu upaya untuk perlindungan hukum yang dilakukan melalui badan peradilan, baik peradilan umum maupun peradilan administrasi negara.

2. Sumber Hukum Perlindungan Pekerja Rumah Tangga adalah sebagai berikut:

a. Undang- Undang dasar Negara Republik Indonesia Tahun 1945.

b. Undang- Undang No.13 Tahun 2003 tentang Ketenagakerjaan.

c. Kitab Undang- Undang Hukum Perdata.

d. Permenaker RI No. 2 Tahun 2015 tentang Perlindungan Hukum Bagi Pekerja Rumah tangga. 


\section{REFERENSI}

Agusmidah. 2017. "Membangun Aturan Bagi Pekerja Rumah Tangga, Mewujudkan Hak Asasi Manusia”, Jurnal Hukum samudra Keadilan, Vol.12, No.1, Januari-Juni2017, Universitas Sumatera Utara.

Anggie Rizqita. 2019. "Perlindungan Hukum Bagi Korban Tinda Pidana Perdagangan Orang Di Indonesia (Legal Protection for Victims of Human Traffiking Crimes in Indodesia)"Jurnal Res Judicata, Vol.2, No.1, Juni 2019, Hal.170-185, Universitas Negeri Semarang.

Arfan Kaimudin. 2019. "Perlindungan Hukum terhadap Tenaga Kerja Anak dalam Peraturan Perundang Undangan di Indonesia”, Jurnal Yurispruden, Vol.2, No.1, Januari2019, Hal.3750, Universitas Islam Malang.

Ida Hanifah. 2020. "Kebijakan Perlindungan Hukum Bagi Pekerja Rumah Tangga Melalui Kepastian Hukum” Jurnal Legislasi Indonesia, Vol.17, No.2 Juni 2020, ISSN.26795562, Universitas Muhammadiyah Sumatera Utara.

Ismiatun. 2017. "Perlindungan Hukum terhadap Pekerja Rumah Tangga Menurut Peraturan Menteri Ketenagakerjaan Nomor 2 Tahun 2015 dalam Perspektif Hukum Positif Hukum Indonesia".

Kansil, C.S.T. 2012. Pengantar Ilmu dan Tata Hukum Indonesia, Jakarta. Balai Pustaka.

Mertokusumo, S. 2009. Penemuan Hukum, bandung, Citra Aditya Bakti.

Muhadar, Edu Abdullah, Husni Thamrin, Perlindungan Saksi \& Korban dalam Sistem Peradilan Pidana, Surabaya, CV Putra Media Nusantara, 2009,

Nur Hidayati. 2015. "Perlindungan terhadap Pembantu Rumah Tangga (PRT) Menurut No.2 Tahun 2015", Ragam Jurnal Pengembangan Humaniora, Vol.14, No.3, Desember 2015, Politeknik Negeri Semarang.

Nurjannah. S. 2012. "Rancangan Undang-Undang Perlindungan Pekerja Rumah Tangga Ditinjau dari Aspek Budaya Hukum Masyarakat Lokal NTB ”, Jurnal Ganec Swara, Vol.6, No.1, Maret2012, Universitas Muhammadiyah Mataram.

Rizky Meitha. 2013. “Tinjauan Perlinmdungan Hukum Pekerja Rumah Tangga (PRT) dalam Kasus Kekerasan dalam Rumah Tangga (KDRT)" Jurnal Recidive. Vol.2, No.3, Sept.-Des 2013, Universitas Sebelas Maret Surakarta.

Sakka Pati (2012) "Perspektif Hukum refleksi terhadap Perlindungan Pekerja Rumah Tangga", Jurnal Amanna Gappa, Vol. 20, No.4, hal.448.

Windi Arista 2019. "Perlindungan Hukum terhadap Hak Konstitusional Pekerja Rumah Tangga", Prosiding Seminar Hukum dan Publikasi Nasional (Serumpun) 1, ISBN:978-623-92439-06. 
Peraturan Menteri Nomor 2 Tahun 2015 Tentang Perlindungan Pekerja Rumah Tangga.

Undang-Undang Dasar Negara Republik Indonesia Tahun 1945 Pasal 28D Ayat (1). 